\title{
WING VEINS OF BEES AS STRENGTHENING ELEMENTS.
}

\author{
Charles Robertson, \\ Carlinville, Illinois.
}

Lutz (1, 182-3) says that if the wing-veins of bees have a function it is probably to strengthen the wing. "However, the 'stingless honey-bees' of the tropics are fairly strong fliers, carry through the air heavy loads of pollen and other material, and are a very successful group, judging by their numbers and their wide distribution, but their wing-venation is so reduced that only a few moderately well-developed cells remain. It would seem from this that the need of an elaborate network of veins to strengthen the wings of bees is not very great, if, indeed, there be such a need." This seems to me an argument from an exceptional case.

The reduction of veins is associated with the importance of the veins as strengthening elements. In 2, 236, the reduction is stated to be associated with small size.

Families of small bees. - The submarginal cells are reduced to two in Panurgidæ, Dufoureidæ, Macropididæ, Prosopididæ, Pasitidæ and Megachilidæ. The Megachilidæ contain some middle-sized bees, but none equaling the largest of the 3-celled species. The typical forms are small, like Prochelostoma, the larger ones being developed from these and retaining the same two cells.

\section{OBLITERATION OR REDUCTION TO STUMPS IN ANAMALOUS CASES.}

The second cubital cell.-This is usually the shortest and the transverse cubital veins 1 and 2 are so approximated that, on the presumption of strength, one of them can be dispensed with. Of 289 cases, one of these veins is obliterated in 286 while the $3 \mathrm{~d}$ transverse cubital is obliterated in only 3 . In Perdita obscurata the 2nd cubital cell is small and petiolate, indicating that in ordinary Perditinæ the two cells are the 1st and 3rd. In one specimen of Pseudopanurgus compositarum transverse cubital vein 
2 is represented by a stump so close to the 1st that it would coalesce with it if produced upward. In a specimen of Phor integer this cell is petiolate. Of 130 specimens of Parandrena andrenoides, which is regularly 2-celled, two show on one side a narrow 2 nd cubital cell closed at the top.

Long and short-tongued nest-makers.-Of 216 cases, a transverse cubital vein is obliterated in 215 short-tongued and only one long-tongued, showing that the reduction occurs in the small wings where they are less important elements of strength.

Long and short-tongued inquilines.-While only one longtongued nest-maker has the veins reduced, 59 long-tongued inquilines have one of them obliterated. On the theory of strength, this may be explained on the ground that strong wings are less important to inquilines. Most inquilines are long-tongued. In the short-tongued Sphecodini, I find 13 specimens with one vein obliterated.

Transverse cubital 2 obliterated.- - Since the first cubital coll is the longest in all of the 226 cases observed, this vein is the one which can be dispensed with without weakening. Usually obliteration of vein 2 leaves two cells of the same size. Vein 2 is obliterated in 226 cases and 1 in only 60 . The 226 cases are Andrenidæ 169, Halictidæ (ex. Sphecodini) 33, Epeolidæ 11, Nomadidæ 6, Sphecodini 3, Colletidæ 3, Euceridæ 1.

Transverse cubital 1 obliterated.-Except that it makes the first cell a little larger, it can be dispensed with in second order. It is wanting in 60 cases, while tr. cu. 2 is wanting in 226 . The 60 cases are Nomadidæ 40, Sphecodini 10, Halictidæ (ex. Sphecodini) 7, Epeolidæ 2, Andrenidae 1. The obliteration in Nomadidae and Sphecodini is peculiar. This, I think, is the vein wanting in Prosopis.

Other veins obliterated.-Transverse cubital 3 is obliterated in 3 cases, 1st recurrent in 1 and 2nd recurrent in 1 . Altogether the transverse cubitals 1 and 2 are obliterated in 286 cases, while more useful veins are wanting in $\mathbf{5}$.

Curiosities.-In Trachandrena claytonioe and Dialonia antennarice tr. cu. 2 is wanting on 1 side, tr. cu. 1 on the other. In two cases, Oxystoglossa confusa and Heminomada obliterata, both are 
wanting on one side. In another case, Holonomada placida, they are wanting on both sides.

Veins increased.-In 3 cases the second cubital cell is divided by a vein which appears as a continuation of the 1st recurrent. In another case the upper part of the $3 \mathrm{~d}$ cubital cell is separated from the lower by a cross vein. So that veins are increased in 4 cases and obliterated in 291.

Enfeeblement of veins.-Instead of proving that the need of strong veins is not great, the reduction in the stingless bees seems to be so unusual as to require an explanation. Comparing with related bees like Bombus, Xylocopa and Eulema would establish a presumption that the reduction is related to the smaller size. The loss of strength comes from a fading out, instead of an obliteration, of the veins. In Curtisapis, the third cubital nervure is enfeebled, while in almost all smaller Halictidæ 2 and 3, and the second recurrent, are weaker. In the small Perditella boltonice the second recurrent vein is almost obsolete. Enfeeblement is pretty regularly correlated with reduction in size.

I have seen bees unable to fly on account of the outer margins being broken. The strength of the nervures may determine how long the wings can be used. Individuals of Meliponidæ may be short-lived. Inquilines have a shorter flight than their hosts, make no nests and have less need for strong wings. They are the almost exclusive long-tongued bees which show anomalous reductions in the venation. In Australia the hive-bee is said to be driving out the native honey-bee. The stronger wings of A pis may have something to do with this.

\section{Literature Cited.}

1. Lutz, F. E. 1924. Apparently non-selective characters and combinations of characters. Ann. N. Y. Acad. Sci. 29: 181-232.

2. Robertson, C. 1910. Hosts of Strepsiptera. Can. Ent. 42 : 323-30. 

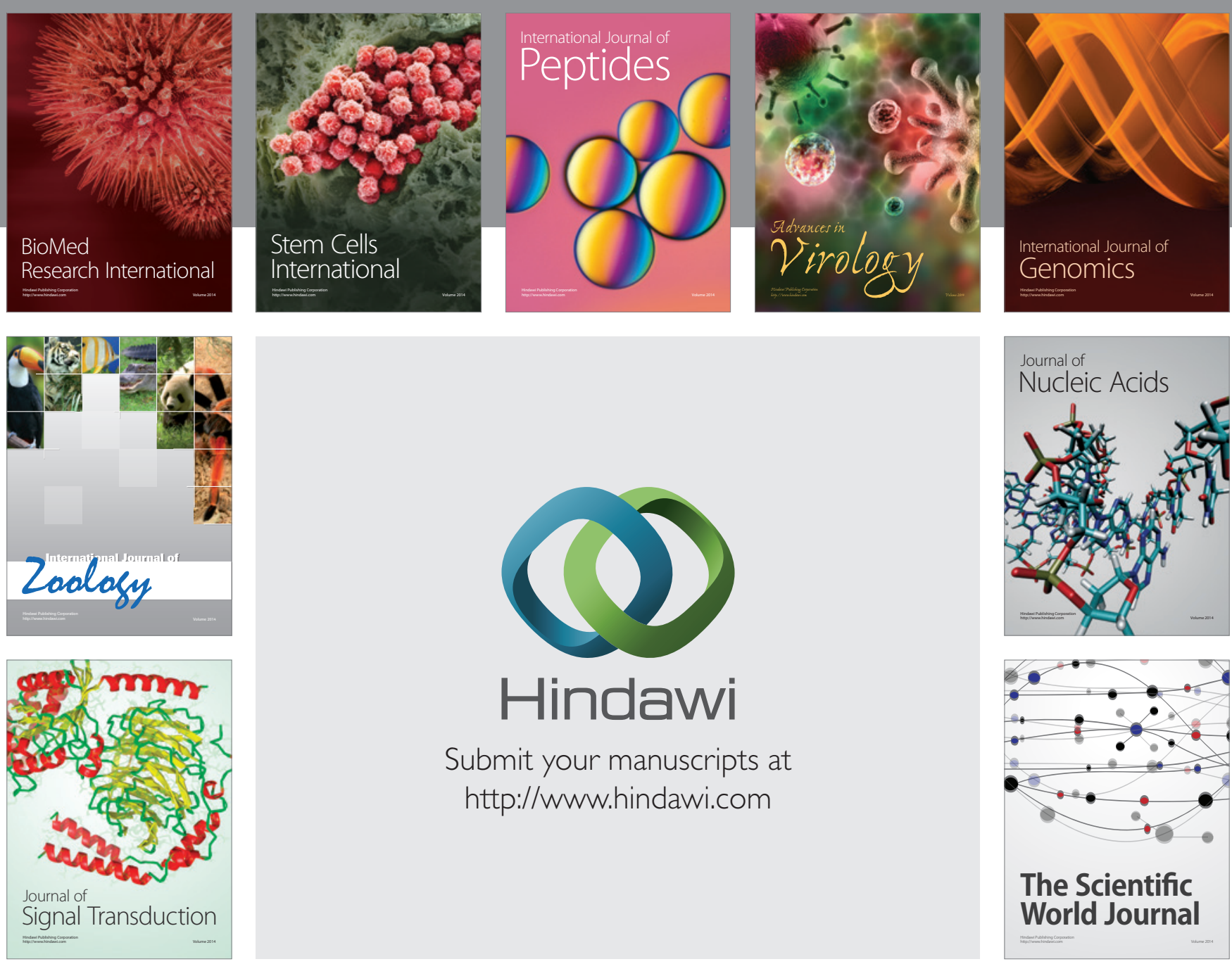

Submit your manuscripts at

http://www.hindawi.com
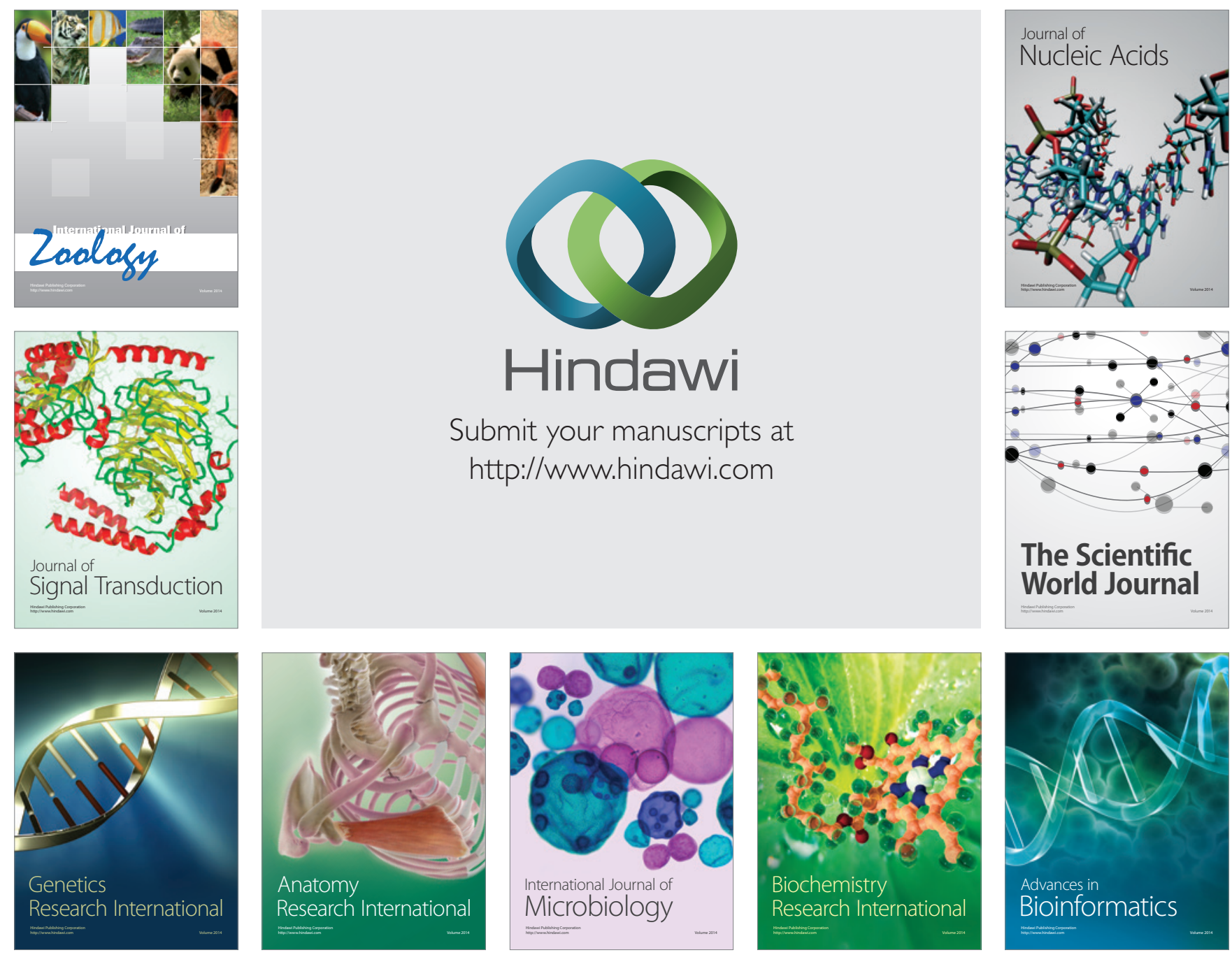

The Scientific World Journal
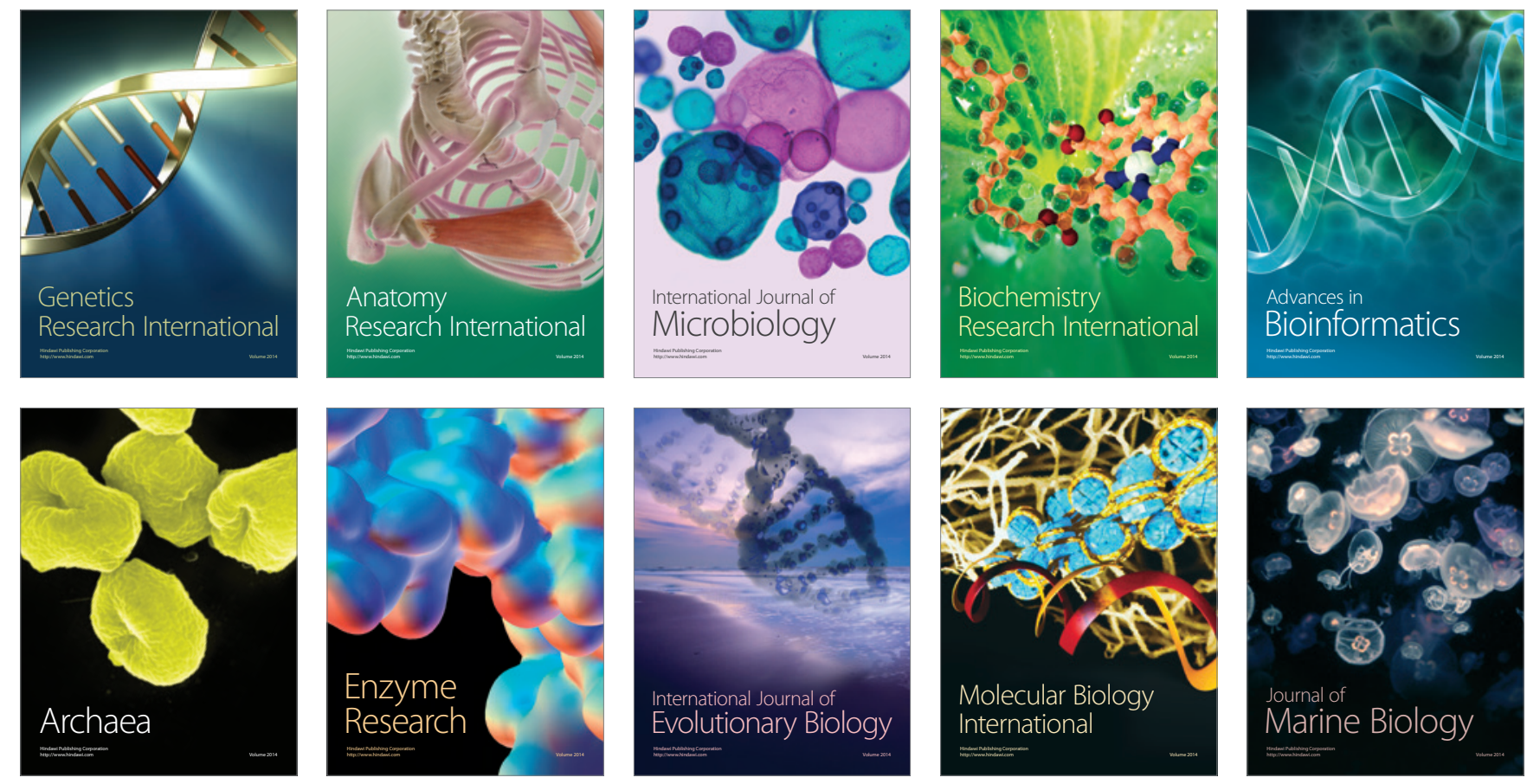